\title{
Experimental and Analytical Study of Partially Replaced Waste Materials in Rigid Pavement
}

\author{
Guruvignesh. $\mathrm{N}^{1}$ | Lavanya.G $\mathrm{G}^{2}$
}

1PG Scholar, Department of Civil Engineering, Anna University Regional Campus, Madurai, Tamil Nadu, India.

${ }^{2}$ Assistant Professor, Department of Civil Engineering, University College of Engineering, Ramanathapuram, Tamil Nadu, India.

To Cite this Article

Guruvignesh N and Lavanya G, "Experimental and Analytical Study of Partially Replaced Waste Materials in Rigid Pavement", International Journal for Modern Trends in Science and Technology, Vol. 06, Issue 05, May 2020, pp.: 84-91; https://doi.org/10.46501/IJMTST060514

Article Info

Received on 20-March-2020, Revised on 24-April-2020, Accepted on 02-May-2020, Published on 07-May-2020.

\section{ABSTRACT}

In India, the $64.5 \%$ of goods transport by road network. The rural road connection improves the Social and economic development of rural area. Generally the village road gets low traffic intensity i.e, 450CVPD. It's necessary to provide cost effective solution for road construction. The construction waste is one of the major wastes generated. In this present study aim is using GGBS and RCA for low cost concreting purpose. In the place of coarse aggregate the Recycled aggregate will be used in the percentage of 0,20,25,30,35\% by the weight of coarse aggregate. In the place of cement the GGBS will be replaced in the percentage of $30 \%$.the recycled aggregate concrete properties is found and compared with non recycled aggregate concrete. Thus properties obtained from various experimental investigations. Based on the various experimental results the pavement thickness is optimized by using IRC58. Present study includes the static response analysis of concrete pavement resting on liquid foundation. The 3 dimensional modeling of pavement purpose ANSYS software used and the analysis result compared with westergaard's analysis. The study shows the finite element tool is reliable tool for concrete analysis

KEYWORDS: Rural road, GGBS, RCA, ANSYS, westergaard's analysis.

Copyright (C) 2014-2020 International Journal for Modern Trends in Science and Technology DOI: https://doi.org/10.46501/IJMTST060514

\section{INTRODUCTION}

The economic and social improvement of any place mainly depends on proper infrastructure. In India more than 6 lakh rural areas need basic transportation facility requirement. The pavements are very essential feature for improving rural communication system. The rigid pavement construction in India became a very popular because of gradual increasing amount of flexible pavement construction. As per IRC: SP: 62-2004 says rigid pavements are one of the best alternative one for flexible pavement. Because flexible pavement not suitable for all type of soil subgrade. In past years since 1920 the thickness of pavement purely form experience basis. The construction waste generation rate is 4.4 million tons per year. And also new concrete pavement preparing time existing concrete removed. So, this project use recycled aggregate waste as partial replacement of conventional concrete. The IS:58 gives thickness optimization guideline. The IS:58 used for structural optimization of recycled aggregate concrete pavement based on experimental results. Analysis of rigid pavement purpose various manual 
analysis methods and finite element software used. In this project the westergaard's analysis and ANSYS software used for analysis purpose. The conventional methods generally used basic assumption of semi infinite plate resting on elastic foundation. This project finds static response of pavement for optimized pavement thickness..

\section{NEEd For The STUdY}

According to the rural road area development plan, the current replacement cost of rural road development is 20,000 crores. This low cost concreting with good strength is suitable for up to 450 CVPD. Followings are the general need for the study,
A. To increase Reusing waste material in future.
B. Form green concrete by using waste material.
C. Reduce the amount for concrete making.
$D$. Avoid time duration for model making in field Final Stage

\section{Limitation Of The Project Work}

Those are limitations of this project work.

A. Performance depend on types of loading

B. Assumption of material properties are made such as Isotropic, linear.

C. Pavement analysis depends on material properties such as poison's ratio \& young's modulus.

\section{LITERATURE REVIEW}

To get the proper idea about the property of materials in concrete purpose various research papers were under the project topic is collected and study was carried out. Followings are common literature review.

S. Jagadeesh et al. (2018). Carried out the study, the pozzolanic material improves the strength with triple mixing approach. The triple mixing approach will increase the RCA properties by surface coating of pozzolonic material with RCA concrete surface. The RCA used by the percentage of $25 \%, 50 \%, 75 \%$ and $100 \%$. The RCA contain huge amount of water absorption capacity. The characters of RCA concrete and non RCA concrete was concluded in this report.

Animesh Awasthi et al. (2018) carried out the experimental studies for adding RCA by partial addition of coarse aggregate $I$ the range of $0,12,20,30,40$ and $50 \%$. The silica fume added instead of cement in partial amount. The RCA addition affect the water absorption and workability reduction but, addition of those materials reduce the demerits. The experimental result shows $30 \%$ of replacement of waste materials gives better performance compared with other replacement mixes.

Krishnaveni.S et al. (2018) examined the GGBS (ground granulated blast furnace slag) as partial replacement of cement and garbage ash replaced partial replacement of fine aggregate. The GGBS replace in the percentage of $40 \%$ and garbage ash replaced in the percentage of $0,10,20,30 \%$ for $M 30$ grade. The comparative study carried between conventional and replaced concrete. The study result shows addition of GGBS reduces the cement content and also reduces the $\mathrm{CO}_{2}$ emission. The optimum mix is $40 \%$ GGBS $+20 \%$ garbage ash replacement. The cost of GGBS is three times lesser than cost of cement include packing, transportation.

\section{RELATED WORK}

This paper explains two methods can be used to determine the stresses and deflection. before every method analysis optimization of pavement thickness required. The designing of pavement thickness require the compressive strength of concrete specimen. Nevile and brooks recommended formula used for compute the static modulus from the compressive strength. The croney and croney formula used for find out the flexural stress. The thickness of pavement designed as per IRC58 with the help of pickett chart. The westergaard analysis time the wheel load applied on semi circular or elliptical manner. So, the circular contact area find from IRC:58 formula. after the westergaard analysis the ANSYS analysis carried with liquid foundation assumption. This analysis time the soil subgrade stiffness was assumed.

\section{Experimental Details}

A. Materials used in this study

(1) Cement: The OPC 53 conforming to Indian standard. This cements having specific gravity of 3.15. and the consistency of the cement is $32 \%$. The initial setting time and final setting time of the cement ar 40 and 590 mins. The finess of the cement is $2.33 \%$

(2) Fine aggregate: in this project fine aggregate purpose M-sand was used. The fine aggregate have a specific gravity of 2.667 . the grading of fine aggregate is zone II. The bulk density of fine 
aggregate is $1444.4 \mathrm{~kg} / \mathrm{m}^{3}$. The voids ratio of sand is $45.8 \%$. Therefore the fine aggregate is angular in nature.

(3) GGBS: the GGBS is by product of blast furnace. The GGBS mixed concrete have slow hydration process. The bulk density of GGBS used is 1200 $\mathrm{kg} / \mathrm{m}^{3}$. The GGBS replaced $30 \%$ by the weight of cement.

(4) Coarse aggregate: the specific gravity of the coarse aggregate is 2.67 . The $20 \mathrm{~mm}$ size crushed angular type of coarse aggregate is adopted for experimental purpose. The abrasion value of aggregate is $23 \%$. The abrasion value is less than $40 \%$ so it's suitable for pavement purpose. The bulk density of the coarse aggregate is $1746 \mathrm{~kg} / \mathrm{m}^{3}$.

(5) RCA: the RCA obtained from construction site at tirupur, Tamilnadu. The specific gravity of RCA is 2.534 . the water absorption is $2.553 \%$. the water absorption value is high compares to conventional. the abrasion value is $35 \%$. The abrasion value is less than $40 \%$. So it's suitable for road works.

B. Minimum grade of concrete mix.

As per IRC44:2017 guidelines for cement concrete mix design of rigid pavement for rural area must have a minimum flexural strength of $3.8 \mathrm{Mpa}$. that's mean minimum grade of concrete for pavement is M30. The following is mi proportion of following experimental studies.

Mix ratio: 1:1.707:2.915:0.45

Cement $=400 \mathrm{~kg} / \mathrm{m}^{3}$

Fine aggregate $=683 \mathrm{~kg} / \mathrm{m}^{3}$

Coarse aggregate $=1166 \mathrm{~kg} / \mathrm{m}^{3}$

Water $=180 \mathrm{~kg} / \mathrm{m}^{3}$

C. Compressive strength result and discussion

The concrete moulds confirming to IS:10086-1982 in the size of $15 \times 15 \times 15 \mathrm{~cm}$ used. The GGBS replaced instead of cement. The RCA used instead of coarse aggregate. The 5 replacement trial was used. Trial1 means 30\% GGBS $+0 \%$ RCA. Trial 2 means $30 \% \mathrm{GGBS}+20 \%$ RCA. Trial 3 means $30 \% G G B S+25 \%$ RCA. Trial 4 means 30\%GGBS+ $30 \%$ RCA. Trial 5 means 30\%GGBS+35\%RCA. The following result shows compressive strength details of various trial mixs.

Table1. compressive strength

\begin{tabular}{|l|l|l|}
\hline S.no & $\begin{array}{l}\text { Trial } \\
\text { number }\end{array}$ & $\begin{array}{l}\text { Average compressive } \\
\text { strength } \mathrm{N} / \mathrm{mm}^{2}\end{array}$ \\
\hline 1 & Trial 1 & 32.93 \\
\hline 2 & Trial 2 & 31.45 \\
\hline 3 & Trial 3 & 31.78 \\
\hline 4 & Trial 4 & 32.61 \\
\hline 5 & Trial 5 & 31.57 \\
\hline
\end{tabular}

The compressive strength of replaced aggregate concrete is higher than the require strength (30
$\mathrm{N} / \mathrm{mm}^{2}$ ). The trial1 contain higher strength but it's not contain any recycled aggregate. The below graph represent the strength variation of various trials.

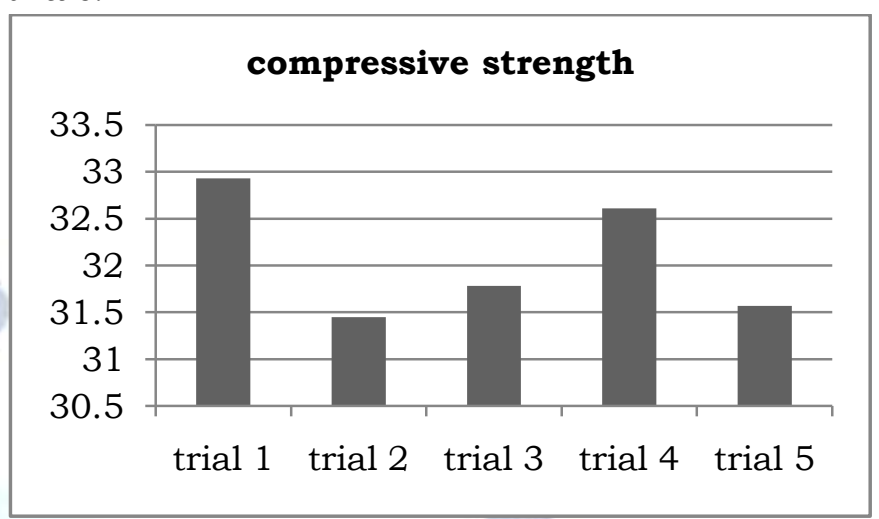

Fig1. compressive strength

The experimental investigation shows that trial4 (30\%GGBS $+30 \%$ RCA) gives maximum compressive strength compare to the other RCA mixes. By adding GGBS with RCA during mix made carbine( carbon with 3non connected electron) made connection between RCA adhered surface during hydration process. This process made concrete stronger.

D. Split tensile strength result and discussion

The cylinder size of dia of $15 \mathrm{~cm} \times 30 \mathrm{~cm}$ is used for testing purpose. As per Indian standard three specimen made and tested. Following table represent the split tensile strength.

Table2. split tensile strength

\begin{tabular}{|l|l|l|}
\hline S.no & Trial number & $\begin{array}{l}\text { Average split tensile } \\
\text { strength } \mathrm{N} / \mathrm{mm}^{2}\end{array}$ \\
\hline 1 & Trial 1 & 2.85 \\
\hline 2 & Trial 2 & 2.77 \\
\hline 3 & Trial 3 & 2.81 \\
\hline 4 & Trial 4 & 2.84 \\
\hline 5 & Trial 5 & 2.76 \\
\hline
\end{tabular}

The split tensile strength of recycled aggregate is nearly equal to non replaced aggregate concrete. The trial 1 get maximum strength but its not contain RCA. The below graph represent the strength variation of various trials.

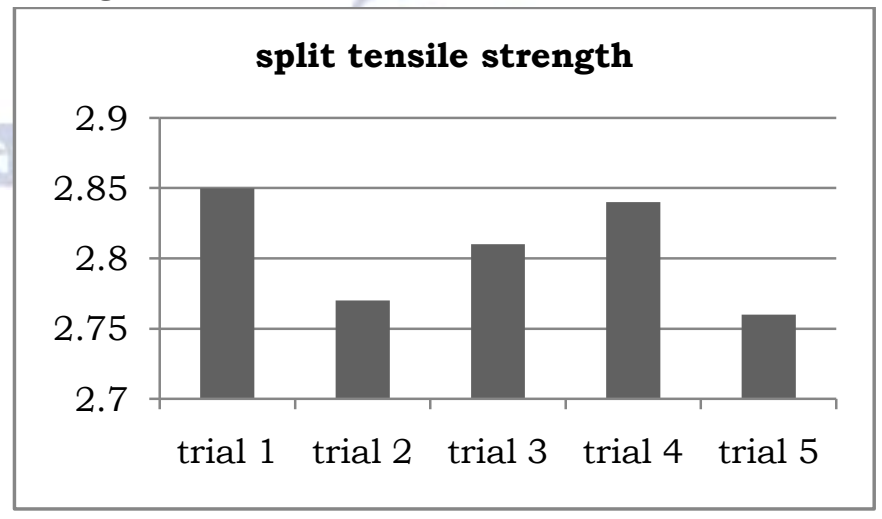

Fig2.split tensile strength

Adding RCA made lower split tensile strength 
compare to trial 1 . The lowest value of split tensile strength was observed for Trial 5 (35\% recycled aggregates). The reason is presence of old cement mortar film hinders the formation of new inter transitional zone, because the adhesion requirement of GGBS is low and pores in old concrete film is high. It's leading to decrease strength of concrete mix. The experimental investigation shows that Trail 4 (30\%GGBS+30\%RCA) gives the maximum split tensile strength compare to the other RCA mixes. This is due to the reason that GGBS particles are finer, spherical which means that they have high specific area which leads to good pozzolanic action. That pozzolanic action made after GGBS filled the pores of old concrete film. That's made the old film of adhered cement mortar phase leads to formation of even stronger, newer inter transitional zone of new concrete.

\section{Optimization of Slab Thickness}

The flexural strength values are obtained by using compressive strength value of concrete cubes with the help of IS456 \& croney and croney formula, accordance with IRC58. The low volume roads (450CVPD) and traffic intensity assumed as a single tandem (cannot predict accurately) considered. So, the design life period of 20years considered. The two lane village road designed with following design parameters.

$\begin{array}{ll}\text { Sub grade reaction modulus }(\mathrm{K}) & =8 \mathrm{~kg} / \mathrm{cm}^{2} \\ \text { Poison's ratio }(\mu) & =0.15 \\ \text { Thermal expansion }(\mathrm{a}) & =10 \times 10^{-6} /{ }^{\circ} \mathrm{C} \\ \text { Tyre pressure (q) } & =8 \mathrm{~kg} / \mathrm{cm}^{2} \\ \text { Rate of traffic increase } & =0.075 \\ \text { Spacing between joints } & =3.5 \mathrm{~m} \\ \text { Width of slab } & =3.5 \mathrm{~m} \\ \text { Design life } & =20 y e a r s\end{array}$

The normal axel load spectrum obtained from axle survey. but in this case basic assumption for rural road was made. only single axel load occurs. It's suitable for low cost concreting. In this following design made for maximum CVPD in other district roads by using IRC 58 data. The detailed designs are given in appendix A.

Table3.design thickness of pavement

\begin{tabular}{|l|l|l|l|}
\hline s.no & Trial name & Thickness $(\mathrm{mm})$ & Fatigue life \\
\hline 1 & Trial 1 & $320 \mathrm{~mm}$ & 0.983 \\
\hline 2 & Trial 2 & $330 \mathrm{~mm}$ & 0.625 \\
\hline 3 & Trial 3 & $330 \mathrm{~mm}$ & 0.669 \\
\hline 4 & Trial 4 & $325 \mathrm{~mm}$ & 0.776 \\
\hline 5 & Trial 5 & $330 \mathrm{~mm}$ & 0.719 \\
\hline
\end{tabular}

As per IRC58 fatigue life is less than 1 . So, the design is safe from fatigue life considerations. This result shows addition of RCA increase the pavement thickness. The trail mix 4 gets low thickness compare to other RCA mixed trials. But, thickness of trial 4 is greater than trial mix 1 .

\section{WESTERGAARD'S RESPONSE}

Since 1920's, the designing of slab thickness follows the Harald Malcolm Westergaard's (1888 -1950) method. Every Indian code practice for pavement design used westergaard's analysis with assumptions like. Soil is elastic and semi infinite and horizontal deformation is zero. IS58-2002 also makes the reference of westergaard's analysis. The following two stresses list out by IS58-2002 with the help of westergaard's analysis

A. Edge stress

i) Due to load

ii) Due to temperature

B. Corner stress

the followings explain the above response as per IRC 58.

\section{A. Temperature stress}

Temperature stresses are developed in pavement plate due to presence of temperature variation between slab thickness and soil layers. Edge region's temperature difference find from westergaard's analysis. The westergaard using bradbury's coefficient using following relation

$$
\mathrm{S}_{\mathrm{te}}=\mathrm{CEat} / 2
$$

The temperature stress calculations mentioned in appendix B. the temperature analysis purpose the Madurai, Tamilnadu location was choose. The annual average temperature of the location is $28.8^{\circ} \mathrm{C}$.the followings are temperature stress obtained from relation

Table4.temperature response

\begin{tabular}{|l|l|l|l|}
\hline Trial name & $\begin{array}{l}\mathrm{S}_{\mathrm{te}} \\
\left(\mathrm{Kg} / \mathrm{cm}^{2}\right)\end{array}$ & $\begin{array}{l}\text { Total of Ste } \\
\text { and } \\
\text { maximum } \\
\text { axle load } \\
\left(\mathrm{Kg} / \mathrm{cm}^{2}\right)\end{array}$ & $\begin{array}{l}\text { Flexural } \\
\text { strength } \\
\left(\mathrm{Kg} / \mathrm{cm}^{2}\right)\end{array}$ \\
\hline Trial 1 & 12.75949 & 36.759 & 40.96 \\
\hline Trial 2 & 11.82721 & 35.827 & 40.03 \\
\hline Trial 3 & 11.75715 & 35.757 & 40.23 \\
\hline Trial 4 & 12.19097 & 36.19 & 40.76 \\
\hline Trial 5 & 11.73145 & 35.73 & 40.10 \\
\hline
\end{tabular}

The total of temperature warping stress and the highest axle load stress is less than the flexural strength. So the pavement thickness of various mixes is safe under the combined action of wheel load and temperature. Corner temperature stress is negligible one because; the corners get free from warping. 


\section{B. Corner stress}

Corner loading is the case in which "the one wheel load is at the corner". The pressure is assumed to be distributed uniformly over the area of a small semi-circle with the centre at the edge". The load stress in the corner region may be obtained as per westergaard's analysis, modified by Kelly according to IRC58 from the following equation

$$
\mathrm{S}_{\mathrm{c}}=\left(3 \mathrm{P} / \mathrm{h}^{2}\right)\left(1-(\mathrm{a} \sqrt{ } 2 / 1)^{1.2}\right)
$$

The following results shows corner stress for the optimized pavements. Details of radius of equivalent circular contact area (a) is given in appendix B.

Table 5. Corner stress

\begin{tabular}{|l|l|l|l|}
\hline $\begin{array}{l}\text { Trail mix } \\
\text { number }\end{array}$ & $\begin{array}{l}\text { Corner } \\
\text { stress } \mathrm{S}_{\mathrm{c}} \\
\left(\mathrm{Kg} / \mathrm{cm}^{2}\right)\end{array}$ & $\begin{array}{l}\text { Deflection } \\
\square(\mathrm{mm})\end{array}$ & $\begin{array}{l}\text { Flexural } \\
\text { strength } \\
\left(\mathrm{Kg} / \mathrm{cm}^{2}\right)\end{array}$ \\
\hline Trial 1 & 16.272 & 0.68554 & 40.96 \\
\hline Trial 2 & 15.455 & 0.665142 & 40.03 \\
\hline Trial 3 & 15.462 & 0.664242 & 40.23 \\
\hline Trial 4 & 15.865 & 0.674037 & 40.76 \\
\hline Trail 5 & 15.458 & 0.664814 & 40.10 \\
\hline
\end{tabular}

The corner stress is less than the flexural strength. So the pavement thickness of various mixes is safe.

\section{Edge stress}

Edge loading is the case in which "the wheel load is at the edge, but at a considerable distance from any corner". The pressure is assumed to be distributed uniformly over the area of a small semi-circle with the edge". as per westergaard analysis, modified by teller and Sutherland, according to IRC58 edge stress becomes $\sigma=\left[0.529 \mathrm{xP} / \mathrm{h}^{2}\right)(1+0.54 \mu)(4 \mathrm{xlog}(1 / \mathrm{b})+\log \mathrm{b}-0.4048]$

Table 6. Edge stress

\begin{tabular}{|l|l|l|l|}
\hline $\begin{array}{l}\text { Trail mix } \\
\text { number }\end{array}$ & $\begin{array}{l}\text { Edge } \\
\text { stress } \sigma \\
\left(\mathrm{Kg} / \mathrm{cm}^{2}\right)\end{array}$ & $\begin{array}{l}\text { Deflection } \\
\square(\mathrm{mm})\end{array}$ & $\begin{array}{l}\text { Flexural } \\
\text { strength } \\
\left(\mathrm{Kg} / \mathrm{cm}^{2}\right)\end{array}$ \\
\hline Trial 1 & 15.303 & 0.3335 & 40.96 \\
\hline Trial 2 & 14.527 & 0.3225 & 40.03 \\
\hline Trial 3 & 14.534 & 0.3221 & 40.23 \\
\hline Trial 4 & 14.917 & 0.3273 & 40.76 \\
\hline Trail 5 & 14.530 & 0.3224 & 40.10 \\
\hline
\end{tabular}

The edge stress is less than the flexural strength. So the pavement thickness of various mixes is safe.

\section{ANSYS RESPONSE}

The FEA was developed in the year of 1943 by R.Courant and he used ritz methods to find the vibration system purpose. The same, the finite element analysis is numerical method to find approximate solution to various engineering related problems. The ANSYS analysis purpose some assumptions was made. Like the material is linear, isotropic and elastic. The model making and support conditions and loading conditions are applied based on wastergaard's assumption for finding exact solution. For example the supports of liquid foundation (elastic support) provided because the westergaard's analysis assumption is pavement free for vertical deformation and deformation restricted to horizontal direction. So, ANSYS also use the same assumption. The following steps are generally complete for modeling and analysis of structure.
1) Engineering data
2) Geometry
3) Model
4) Setup
5) Solution

\section{A. PROBLEM STATEMENT}

Concrete Plate is of size $3.5 \mathrm{~m} \times 3.5 \mathrm{~m}$ having thickness depend on mix type is created in static structure analysis in ANSYS. A load of $8000 \mathrm{~kg}$ (78456KN) applied based on IS58-2002 guidelines. Load applied on circular contact area of radius calculated by IS58-2002 guidelines. Foundation for plate (rigid structure) is modeled as liquid foundation and Spring foundation having foundation stiffness $\mathrm{k}=8 \mathrm{~kg} / \mathrm{cm}^{3}$ and Poisson's ratio is 0.15 respectively. 8 noded solid element is used for model creation and tetrahedron element type of meshing is used to model the pavement with 100 $\mathrm{mm}$ mesh size. The ANSYS used values listed in appendix $\mathrm{C}$

\section{B. ANSYS solution for corner loading}

The one wheel load applied on the corner. As per westergaard's guidelines the corner load applied on circular manner. Radius of equivalent circular contact area of tyre is $26.51 \mathrm{~cm}$. The following figures obtained from ANSYS corner analysis. Fig. 3 (a) shows corner loading position on the pavement. (b) Shows the meshing.(c) shows the support and loading condition.(d) Shows deflection at the loading position.(e) Shows stresses developed at the corner of the pavement.(f)shows equivalent (von-mises) stress at the loading position.
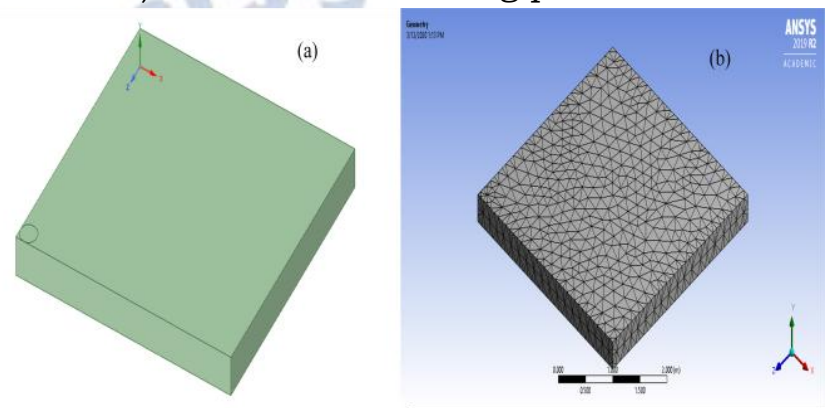



(d)
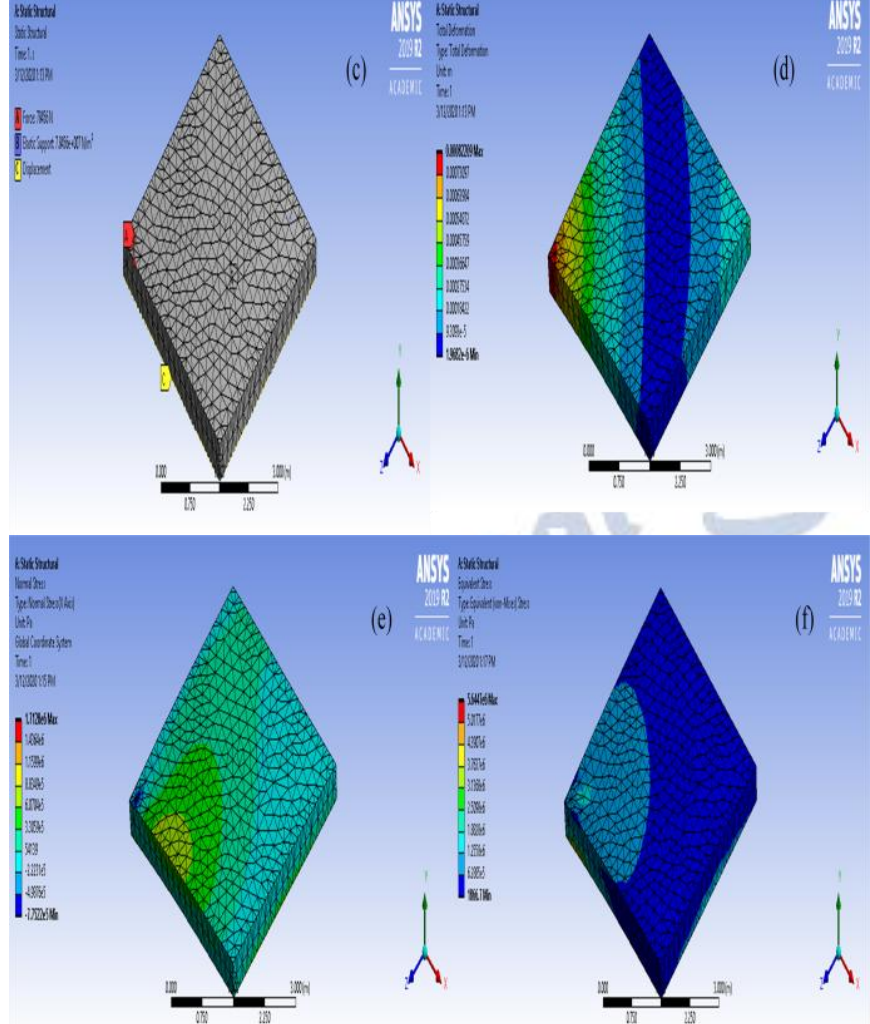

Fig.3. ANSYS corner load analysis

The maximum total deformation, normal stress and equivalent stress details as shown in below table7

Table 7. ANSYS corner load analysis

\begin{tabular}{|l|l|l|l|}
\hline $\begin{array}{l}\text { Mix } \\
\text { number }\end{array}$ & $\begin{array}{l}\text { Maximum total } \\
\text { deformation } \\
(\mathrm{mm})\end{array}$ & $\begin{array}{l}\text { Normal } \\
\text { stress } \\
(\mathrm{Mpa})\end{array}$ & $\begin{array}{l}\text { Equivalent } \\
\text { stress (Mpa) }\end{array}$ \\
\hline Mix1 & 0.8220 & 1.7128 & 5.64 \\
\hline Mix2 & 0.8075 & 1.7105 & 4.9881 \\
\hline Mix3 & 0.8063 & 1.7111 & 4.9892 \\
\hline Mix4 & 0.8137 & 1.8014 & 5.4942 \\
\hline Mix5 & 0.8068 & 1.7109 & 4.9886 \\
\hline
\end{tabular}

The ANSYS graphical result shows the maximum deformation and stress concentration high on corner loading area. Commonly the deformation was reduced in optimum percentage for static fix base. But, rigid pavement contains elastic foundation; it's freely allowing deformation on vertical direction. So, optimum contains high deformational characters. The result shows trial mix4 is optimum. Trial 1 contains good deformational character. But, it's conventional and objective of the project is finding suitable trial mix. In this project von-mises stress used for find concrete fatigue strength. The vonmises result shows the trial 4 gives better result compared to trial2, trial3, trial5 and trial 4 nearly equal to trial1. And also normal stress on the trial 4 becomes higher than other trials. i.e., optimum is trial 4.

\section{ANSYS solution for edge loading}

The one wheel load applied on the edge of the pavement, but at a considerable distance from any corner. As per westergaard's guidelines the edge load applied on circular manner. Radius of equivalent circular contact area of tyre is not constant for edge loading because $a / h$ is less than 1.724. The circular contact area for tyre is tabulated in appendix $\mathrm{C}$. The following figures obtained from ANSYS edge analysis. Fig.4 (a) shows corner loading position on the pavement. (b) Shows the meshing.(c) shows the loading condition.(d) Shows deflection at the loading position.(e) Shows stresses developed at the corner of the pavement.(f)shows equivalent (von-mises) stress at the loading position.
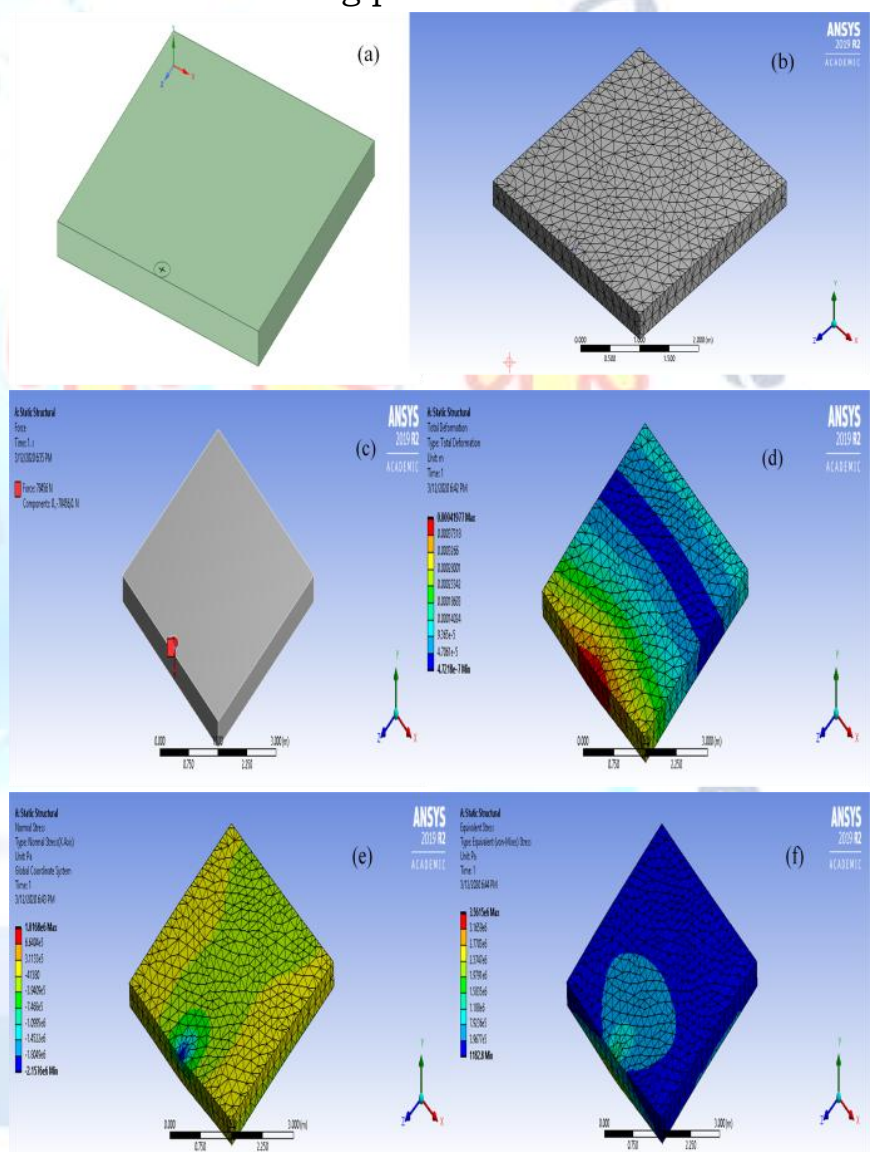

Fig 4. ANSYS edge load analysis

The maximum total deformation, normal stress and equivalent stress details as below

Table. 8 ANSYS edge load analysis

\begin{tabular}{|l|l|l|l|}
\hline $\begin{array}{l}\text { Mix } \\
\text { Number }\end{array}$ & $\begin{array}{l}\text { Total } \\
\text { Deformation } \\
(\mathrm{Mm})\end{array}$ & $\begin{array}{l}\text { Normal } \\
\text { stress } \\
(\mathrm{Mpa})\end{array}$ & $\begin{array}{l}\text { Equivalent } \\
\text { Stress (Mpa) }\end{array}$ \\
\hline Mix1 & 0.4197 & 1.016 & 3.5615 \\
\hline Mix2 & 0.4167 & 1.0044 & 2.9016 \\
\hline Mix3 & 0.4153 & 1.0045 & 2.902 \\
\hline Mix4 & 0.4149 & 0.94052 & 3.2425 \\
\hline Mix5 & 0.4152 & 1.0045 & 2.9018 \\
\hline
\end{tabular}


The above result shows the maximum deformation and stress concentration high on edge loading area. The normal stress and deformation of tril 4 is low. But, The vonmises result shows the trial 4 gives better result compared to trial2, trial3, trial5 and trial 4 nearly equal to trial1. i.e., optimum is trial 4.

\section{COMPARISON OF WESTERGAARD'S AND ANSYS ANALYSIS}

1) Corner loading stresses, deflection calculated by ANSYS are higher than by analytical solution. The ANSYS solutions nearly $22-25 \%$ higher than the westergaard's solution.

2) Edge loading stresses calculated by ANSYS are lower than by analytical solution .ie., nearly $22-25 \%$. But, edge loading deflection calculated by ANSYS is higher than by analytical solution.

\section{E. Reason for result variation}

The westergaard's method is applicable only to a slab on a liquid foundation. The liquid foundation means foundation contains infinite spring at the foundation and allows deformation freely based on stiffness of spring. At the time of analysis stiffness means soil stiffness (subgrade reaction). The soil is assumed as elastic and semi-infinite. Semi-infinite means two sides near the loading place assumed as fixed and other two boundaries considers as infinite. The ANSYS analysis also assumes the winkler foundation. But, the plate constrains are assumed in infinite. Because, ANSYS cannot give proper deflection response if the two ends are fixed. ANSYS required proper constrains. The following diagram fig5. is general conceptual diagram for above concept,
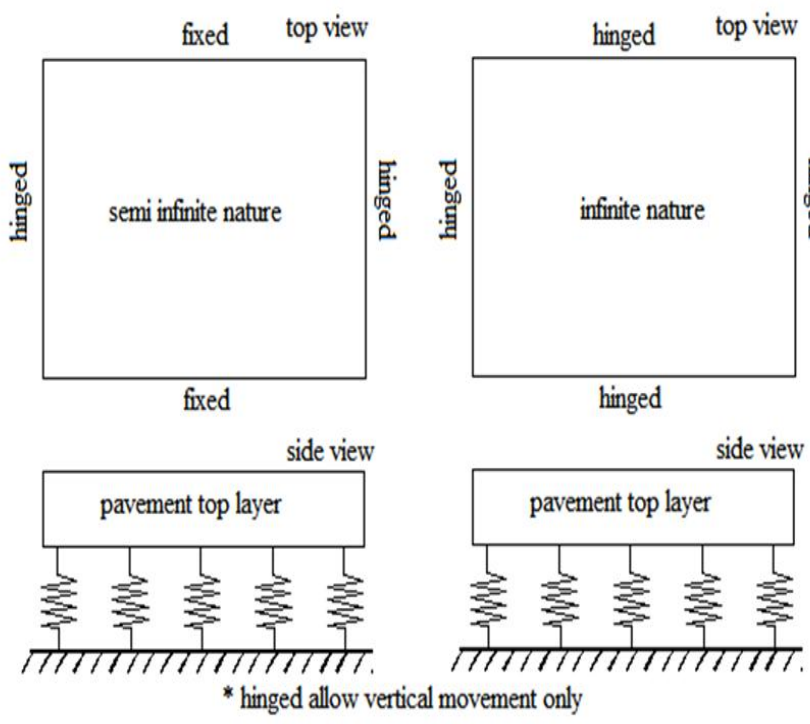

(A) westergaard's model

(B) ANSYS model

\section{Conclusion}

The study presented in this project is conducted to evaluate the material properties, compressive strength, split tensile strength, flexural strength, design and cost aspect, westergaard's analysis, ANSYS analysis for various trial mixes. The following main conclusions drawn from this study, 1) From the materials testing, the RCA gets high water absorption capacity. But, the abrasion value of RCA is safe with in permissible limit.

2) The experimental investigation shows that Trail $4(30 \%$ GGBS $+30 \%$ RCA) gives the maximum compressive strength and tensile strength compare to the other RCA mixes. Due to, GGBS made carbyne bond character. . The RCA with GGBS make a improve microstructure of interfacial transition zone.

3) The design of rigid pavement evolved as per IRC: $58-2002$, the thickness of pavement for various trial mixes is $32 \mathrm{~cm}, 33 \mathrm{~cm}, 33 \mathrm{~cm}, 32.5 \mathrm{~cm}$ and $33 \mathrm{~cm}$.

4) From the westergaard's analysis, the total of temperature warping stress and the highest axle load stress, the corner stress, the edge stress is less than the flexural strength. So the pavement thickness of various mixes is safe under the combined action of wheel load and temperature.

5) The ANSYS result shows, trial mix4 is optimum and it's contains good deformational character compared with other replacement mixes. A conclusion section is not required.

6) Due to infinite character of ANSYS analysis, the ANSYS result doesn't match with westergaard's analysis.

\section{APPENDIX}

APPENDIX-A DESIGN DATA OF SLAB THICKNESS

table.single axle load spectrum

\begin{tabular}{|c|c|}
\hline Single axel load & $\sqrt{2+2}$ \\
\hline Axle load class, tons & $\%$ of axle load \\
\hline $19-21$ & 0.6 \\
\hline $17-19$ & 1.5 \\
\hline $15-17$ & 4.8 \\
\hline $13-15$ & 10.8 \\
\hline $11-13$ & 22 \\
\hline $9-11$ & 23.3 \\
\hline$<9$ & 30 \\
\hline Total & 93.0 \\
\hline
\end{tabular}

Cumulative number of repetition

$\mathrm{C}=365 \mathrm{xA}\left((1+\mathrm{r})^{\mathrm{n}}-1\right) / \mathrm{r}$

$=365 \times 450\left((1+0.075)^{20}-1\right) / 0.075=7,112,793.91$

Design traffic $=25 \%$ of total repetitions

Fig 5. Model details 
$=25 \mathrm{x} 7,112,793.91 / 100=1,778,198.477$ (the design traffic of $25 \%$ considered for total two lane because of exact estimate against fatigue failure purpose)

Table. Expected repetitions

\begin{tabular}{|c|c|}
\hline \multicolumn{2}{|c|}{ Single axel load } \\
\hline Axle load, tons & Expected repetition \\
\hline 20 & 10669.19 \\
\hline 18 & 26672.98 \\
\hline 16 & 85353.53 \\
\hline 14 & 192045.4 \\
\hline 12 & 391203.7 \\
\hline 10 & 414320.2 \\
\hline$<10$ & 533459.5 \\
\hline
\end{tabular}

Flexural stress(as per IS 456) $\quad=0.7 \sqrt{ } \mathrm{f}_{\mathrm{ck}}$ croney and croney flexural formula $=0.36 \mathrm{f}_{\mathrm{ck}} 0.7$

Nevile and brooks recommended the following expression for computing static modulus from the cubic compressive strength $\mathrm{E}=9100 \mathrm{f}_{\mathrm{ck}} 0.33$

Table.Flexural and young's modulus

\begin{tabular}{|l|l|c|}
\hline $\begin{array}{l}\text { Trail mix } \\
\text { number }\end{array}$ & $\begin{array}{l}\text { Flexural } \\
\text { strength } \\
\left(\mathrm{Kg} / \mathrm{cm}^{2}\right)\end{array}$ & $\begin{array}{c}\text { Young's } \\
\text { modulus } \\
(\mathrm{MPa})\end{array}$ \\
\hline Trial 1 & 40.96 & 28830.134 \\
\hline Trial 2 & 40.03 & 28395.937 \\
\hline Trial 3 & 40.23 & 28493.918 \\
\hline Trial 4 & 40.76 & 28737.379 \\
\hline Trail 5 & 40.10 & 28431.646 \\
\hline
\end{tabular}

APPENDIX-B

DESIGN DATA FOR TEMPERATURE STRESS

$\mathrm{I}=$ radius of relative stiffness

$=\sqrt[4]{\left(\operatorname{Eh}^{3} /\left(12\left(1-\mu^{2}\right) \mathrm{k}\right)\right)}$

Table. temperature stress

\begin{tabular}{|c|l|l|l|l|l|}
\hline $\begin{array}{l}\text { Mix } \\
\text { no }\end{array}$ & $\begin{array}{c}\text { h } \\
(\mathrm{cm})\end{array}$ & $\mathrm{I}(\mathrm{cm})$ & $\begin{array}{l}\mathrm{L} / 1 \\
(\mathrm{~cm})\end{array}$ & $\mathrm{C}$ & $\begin{array}{c}\text { Ste } \\
\left(\mathrm{Kg} / \mathrm{cm}^{2}\right)\end{array}$ \\
\hline 1 & 32 & 100.65 & 3.47 & 0.30 & 12.759 \\
\hline 2 & 33 & 102.61 & 3.41 & 0.28 & 11.827 \\
\hline 3 & 33 & 102.70 & 3.40 & 0.28 & 11.757 \\
\hline 4 & 32.5 & 101.75 & 3.43 & 0.28 & 12.190 \\
\hline 5 & 33 & 102.65 & 3.40 & 0.28 & 11.731 \\
\hline
\end{tabular}

APPENDIX-C

DESIGN DATA FOR ANSYS

TABLE. EQUIVALENT CIRCULAR DIAMETER

\begin{tabular}{|c|c|c|}
\hline S.No & Mix NumBeR & $\begin{array}{c}\text { EQuivalENT CiRCUlAR DiAMETER } \\
(\mathrm{CM})\end{array}$ \\
\hline 1 & MIX1 & 24.751 \\
\hline 2 & MIX2 & 24.772 \\
\hline 3 & MIX3 & 24.772 \\
\hline 4 & MIX4 & 24.760 \\
\hline 5 & MIx5 & 24.772 \\
\hline \multicolumn{2}{|l|}{ Mesh dimension } & $100 \mathrm{~mm}$ \\
\hline \multicolumn{2}{|l}{ Stiffness } & $8 \mathrm{~kg} / \mathrm{cm}^{3}$ \\
\hline
\end{tabular}

\section{REFERENCES}

[1] N.Guruvignesh, G.Lavanya, P.Akila, "A Review: Experimental and Analytical Study of Partially Replaced Waste Materials in Rigid Pavement", International Journal of Innovative Research In Technology (IJIRT),vol.5, issue.6, october2019, pp. 90-97.

[2] S. Jagadeesh, Dr. K. Venkata Ramesh, S. Ganesh, Er. Darapu Srikanth Satish Kumar (2018). "Study on tensile strength properties of recycled aggregate concrete with and without pozzolanic materials". International Journal of Civil Engineering and Technology (IJCIET), Vol9,no.11, pp-671-679.

[3] Animesh Awasthi, Gourav Soni, Ram Bharosh (2018), "Study of Recycled Aggregate Concrete Containing Silica Fume as Partial Replacement for Cement". 'International Journal of Advance Research, Ideas and Innovations in Technology'. Vol4, no.2, pp.239-246.

[4] Krishnaveni.S , Jothi.G , Abdullah.S.K. , Gokul.A , Devarajan.E , Dhivakar.G (2018). "Study on Partial Replacement of Cement by Ground Granulated Blast Furnace Slag (GGBS) and Sand by Garbage ASH". 'International Journal of Engineering Science and Computing'. Vol8,no3. Pp.16787-16791.

[5] IRC 58:2002. "guidelines for the design of plain jointed rigid pavements for highways"

[6] IS 10082-1986. "specification for Moulds for use in tests of Cement and Concrete"

[7] IRC 44: 2017. "guidelines for cement concrete mix design for pavements recommends" 